\title{
The Future Of Affirmative Action After Grutter v. Bollinger
}

\author{
Paula Alexander Becker, (E-mail: alexanpa@shu.edu), Seton Hall University
}

\begin{abstract}
The future of affirmative action was the subject of a pair of consolidated cases decided by the United States Supreme Court in June 2003. Whether the Fourteenth Amendment prohibits the use of race in the admission of students to a University or whether diversity can provide a compelling government interest sufficient to meet Fourteenth Amendment standard was the controversy decided by the Supreme Court. This case will affect the future of affirmative action not only in higher education, but also in the employment arena as well.
\end{abstract}

\section{Discussion}

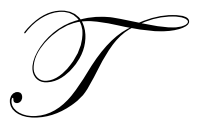

he future of affirmative action was the subject of a pair of consolidated cases decided by the United States Supreme Court in June 2003. ${ }^{1}$ Whether the Fourteenth Amendment prohibits the use of race in the admission of students to a University or whether diversity can provide a compelling government interest sufficient to meet Fourteenth Amendment standard was the controversy decided by the Supreme Court. ${ }^{2}$ This case will affect the future of affirmative action not only in higher education, but also in the employment arena as well.

Title VII of the 1964 Civil Rights Act prohibits discrimination based on race and other ascriptive characteristics in employment decisions. ${ }^{3}$ Title VI of the 1964 Civil Rights Act prohibits the discrimination based on race, color and national origin in any program receiving federal assistance. ${ }^{4}$ However, an affirmative action plan acts as a defense to the impermissible consideration of race under the 1964 Civil Rights Act. ${ }^{5}$ Affirmative consideration of race in decision making has been permitted in the context of prior history of discrimination, and

\footnotetext{
${ }^{1}$ Grutter v. Bollinger, 123 S. Ct. 2325 (2003), and its companion case Gratz v. Bollinger, 123 S. Ct. 2411 (2003).

${ }^{2}$ The Fourteenth Amendment of the United States Constitution provides:

Section 1. All persons born or naturalized in the United States, and subject to the jurisdiction thereof, are citizens of the United States and of the State wherein they reside. No State shall make or enforce any law which shall abridge the privileges or immunities of citizens of the United States; nor shall any State deprive any person of life, liberty, or property, without due process of law; nor deny to any person within its jurisdiction the equal protection of the laws.

Section 5. The Congress shall have power to enforce, by appropriate legislation, the provisions of this article.

${ }^{3}$ Title VII provides:

(a) It shall be an unlawful employment practice for an employer-

(1) to fail or refuse to hire or to discharge any individual, or otherwise to discriminate against any individual with respect to his compensation, terms, condition, or privileges of employment, because of such individual's race, color, religion, sex, or national origin; or

(2) to limit, segregate, or classify his employees or applicants for employment in any way which would deprive or tend to deprive any individual of employment opportunities or otherwise adversely affect his status as an employee, because of such individual's race, color, religion, sex, or national origin. 42 U.S.C. S 2000e- 2.

${ }^{4}$ TitleVI provides "[n]o person in the United States shall, on the ground of race, color, or national origin, be excluded from participation in, be denied the benefits of, or be subjected to discrimination under any program or activity receiving Federal financial assistance." 42 U.S.C. S. 2000d.

542 U.S.C. S 2000e-2(j) provides:

Nothing contained in this subchapter shall be interpreted to require any employer, employment agency labor organization or joint labormanagement committee subject to this subchapter to grant preferential treatment to any individual or to any group because of the race, color, religion, sex, or national origin of such individual or group on account of an imbalance which may exist with respect to the total number or percentage of persons of any race, color, religion, sex, or national origin employed by any employer, refereed or classified for employment to any employment agency or labor organization, admitted to membership or classified for employment by any employment agency or labor organization...
} 
where there is a remedial purpose. ${ }^{6}$ The issue of whether diversity can justify the affirmative consideration of race in the employment context was posed by Taxman v. Board of Education, Township of Piscataway, ${ }^{7}$ but the Taxman case was settled prior to being heard by the Supreme Court. ${ }^{8}$ However, in the educational context, Regents of the University of California v Bakke ${ }^{9}$ arguably established diversity in admission of students as a constitutionally permissible goal in higher education. ${ }^{10}$ While the actual procedures used by the University of California were prohibited as violating constitutional standards, Justice Powell writing for the plurality of the Court, found that universities have an interest in creating a diverse student body. ${ }^{11}$ This is an interest grounded in the first Amendment. ${ }^{12}$

Prior to the Grutter v. Bollinger case, the constitutionality of race-conscious procedures for admission to the University of Texas Law School was challenged in the case, Hopwood v. University of Texas. ${ }^{13}$ The University of Texas Law School utilized a dual track system for admissions whereby a minority admissions subcommittee of the full admissions committee evaluated minority students separately from non-minority students. The trial court in the Hopwood case found that the University of Texas Law School had a compelling government interest in the promotion of a diverse student body under Bakke, but that the admission procedures actually used were unconstitutional, violating the equal protection clause of the Fourteenth Amendment, because the admissions procedures were not narrowly tailored to meet the government's interest in diversity. ${ }^{14}$ The Fifth Circuit reversed the trial court as to its conclusion that diversity served as a compelling government interest, without reaching the issue of whether the University of Texas Law School's admissions procedures were narrowly tailored. ${ }^{15}$ The Supreme Court refused to grant certiorari in the Hopwood case. ${ }^{16}$ In the aftermath of the Hopwood case, many universities stopped considering race in admissions. ${ }^{17}$

The Grutter v. Bollinger and Gratz v. Bollinger cases posed the question: whether the Fourteenth Amendment prohibits the use of race in the admission of students to a University or whether diversity can provide a compelling government interest sufficient to meet Fourteenth Amendment standard. ${ }^{18}$ The University of Michigan developed and used an admission procedure that includes the consideration of race as a factor in admission of students to the Law School. Its procedures, however, were different than those utilized at the University of Texas Law School. The University of Michigan Law School considered race as a factor in admissions, without separate procedures for minority students. Nevertheless, these procedures were challenged by non-minority students denied admission to the Law School. The trial court held that the University of Michigan violated the Fourteenth Amendment by its consideration of race in admission to the Law School. ${ }^{19}$ However, the Sixth Circuit Court of

\footnotetext{
${ }^{6}$ See Johnson v. Transportation Agency, 480 U.S. 616 (1987), Wygant v. Jackson Bd. of Educ., 467 U.S. 267 (1986); United Steelworkers v. Weber, 443 U.S. 193 (1979).

7 832 F. Supp. 836 (D.N.J.1993)

${ }^{8} 91$ F. 3d. 1547 (3d Cir. 1996) (en banc) cert. granted, 117. S. Ct. 2506 (1997). The Taxman case was settled in November 1997, when the Piscataway Township Board of Education voted to settle the case with the plaintiff, Sharon Taxman. The Black Leadership Forum urged the settlement and provided most of the monies to settle the case. See Paula Alexander Becker, Affirmative Action and Reverse Discrimination: Does Taxman v. Board of Education of the Township of Piscataway Define the Outer Limits of Lawful Voluntary Race Conscious Affirmative Action? 8 SETON HALL CONST L.J. 8, 13-46 (1997).

${ }_{9} 438$ U.S. 265 (1978)

${ }^{10}$ The Supreme Court in Grutter v. Bollinger "endorse[d] Justice Powell's view that student body diversity is a compelling state interest that can justify the use of race in university admissions." 123 S. Ct. at 2337.

${ }^{11}$ Bakke, 438 U.S. at 312-313.

12 "The fourth goal asserted by petitioner [Regents, University of California] is the attainment of a diverse student body. This clearly is a constitutionally permissible goal for an institution of high education. Academic freedom, though not a specifically enumerated constitutional right, long has been viewed as a special concern of the First Amendment. The freedom of a university to make its own judgments as to education includes the selection of its student body...The atmosphere of speculation, experiment and creation"-so essential to the quality of higher education - is widely believed to be promoted by a diverse student body." Bakke, 438 U.S. at 311-312 (footnote omitted).

${ }_{13}^{13} 861$ F. Supp. 551 (W.D. Tex. 1994), rev'd78 F. 3d 932 ( $5^{\text {th }}$ Cir. 1996), cert. denied 116 S. Ct. 2581, and cert. denied sub nom. Thurgood Marshall Legal Soc'y v. Hopwood, 116 S. Ct. 2580.

${ }^{14} 861$ F. Supp. 551 (W.D. Tex. 1994)

1578 F. 3d 932 (5 $5^{\text {th }}$ Cir. 1996).

${ }^{16}$ Cert. denied 116 S.Ct. 2581, and cert. denied sub nom. Thurgood Marshall Legal Soc'y v. Hopwood, 116 S. Ct. 2580.

${ }^{17}$ See generally, CHILLING ADMISSIONS: THE AFFIRMATIVE ACTION CRISIS AND THE SEARCH FOR ALTERNATIVES (Gary Orfield and Edward Miller, eds, 1998).

${ }^{18}$ Grutter, 123 S.Ct. 2325, 2335 (2003).

${ }^{19}$ Grutter,1371 F. Supp. 2d 821, 826-38 (E.D. Mich. 2001).
} 
Appeals over-ruled the trial court, specifically relying on the Bakke case. ${ }^{20}$ The United States Supreme Court granted certiorari, to resolve the question of whether diversity is a constitutionally permissible basis for the consideration of race, in the admission of students to institutions of higher education. The United States Supreme Court decided in June 2003 that the Fourteenth Amendment permits the use of race in the admission of students the University because diversity can provide a compelling government interest sufficient to meet the Fourteenth Amendment standard of equal protection, provided that the method used in the admission of students is narrowly tailored to meet the University's interest in a diverse student body. ${ }^{21}$ Thus the University Michigan Law School procedures were upheld as constitutional. However the procedures used for the admission of students to the undergraduate college, whereby minority students were granted 20 points toward their score, when a total of 100 points assured admission to the undergraduate college, were ruled unconstitutional, as not narrowly tailored. ${ }^{22}$

The Supreme Court, in the Grutter case, rejected the position that "remedying past discrimination is the only permissible justification for race-based governmental action." 23 This may have far-reaching implications in the employment context, particularly because the Court noted that leadership of American businesses, fostered in significant ways by institutions of higher education, ${ }^{24}$ requires "skills needed in today's increasingly global marketplace [which] can only be developed through exposure to widely diverse people, cultures, ideas, and viewpoints. ${ }^{25}$ The extension of these cases to the employment arena is a likely development of the law, particularly in view of the Court's reference to leadership skills required of individuals in our present global environment.

Notes

${ }^{20}$ Grutter, 288 F.3d 732, 738 (6 $6^{\text {th }}$ Cir. 2002).

${ }^{21}$ Grutter, 123 S. Ct. at 2341-42.

${ }^{22}$ Gratz v. Bollinger, 123 S. Ct. 2411, 2427 (2003).

${ }^{23}$ Grutter, 123S. Ct. at 2338-39.

${ }^{24} \mathrm{Id}$. at $2340-41$.

${ }^{25} I d$. at 2340. 
Notes 